\title{
THE UTILIZATION OF ENDE BEACH TOURISM OBJECTS AS A LEARNING RESOURCE IN IMPROVING ENGLISH LANGUAGE SKILLS AT ENGLISH LOVER COMMUNITY (ELC) ENDE
}

\author{
${ }^{1}$ Agustina Pali, ${ }^{2}$ Berty Sadipun \\ ${ }^{1,2}$ Faculty of Teacher Training and Education, Flores University \\ indahpali2020@gmail.com
}

\begin{abstract}
A positive natural environment can have positive implications for improving one's English language skills. The analysis of the situation faced by the partners was the minimum mastery of English basic skills, which resulted in a very low level of confidence in using English.This Community Service activity aims to improve the English skills of activity partners who are members of the English Lover Community (ELC) Ende through the use of Ende Beach tourism objects as a source of learning inspiration. The method of community service activities is to carry out mentoring through several stages of organizing and mentoring techniques including interviews, pre-tests, interactive lectures, questions and answers, contextual learning, discussions, drilling, demonstrations and post-tests. This activity had a positive impact on improving the English language skills of Ende's English Lover Community (ELC) participants.English proficiency in this case is an increase in vocabulary and pronunciation mastery of Ende's English Lover Community (ELC) participants both in quantity and quality. In addition, it also has positive implications for the ability to compose learned vocabulary into English sentences and re-express sentences that have been strung into good and correct English pronunciation, as well as an increase in the ability to compose English sentences into short paragraphs and the ability to read these compiled paragraphs with correct English pronunciation and intonation. The improvement in these skills can be seen from the increasing in the average score of pre-test $(60.33 \%)$ to post-test $(81.33 \%)$.
\end{abstract}

Key Words: Improving English Language Skills, Utilization of Ende Beach

\section{INTRODUCTION}

Humans are currently living in a world that is hit by a tremendous change. This change is signaled by the inevitable force of global currents. One of the things that is very visible is the advancement of science and technology which has spurred people to have the ability to communicate internationally. The ability to communicate internationally can make people of different nationalities and cultures get to know each other. Therefore, the role of English as a global language is very vital. One's insight and knowledge will be opened globally if one learns English, (Reddy, 2016). The current implication is that more people or communities are trying to learn and master English well. One of them is the English lover community (ELC) which consists of young people (learner and students) in Ende Regency. The desire of ELC youths in developing their interest in English is quite diverse; one of them is the desire to prepare their self to enter the world of work someday. For them, knowledge of English is not just a trend but it is a today's necessity. The same thing is in accordance with Nishanthi's expression in his writing published in the International Journal of Trend in Scientific Research and Development that "knowledge of English is necessary if one wants to come up in life", (Nishanthi, 2018) which means that if someone wants to progress in his life, knowledge of English is a necessity. This statement shows that English shows a dominating role in life, so we cannot ignore its position.

A person's desire and ambition to master English skills must be accompanied by a struggle and a hard work. There are several important skills that must be mastered in 
English, including speaking, reading, writing and listening, (Geoffrey, Broughton, Brumfit. C., Flavell. R., Hill. Peter, 2003). One of the most fundamental factors for a person to master these four skills is vocabulary mastery (English vocabulary), (Kurniawan, 2016), (Sa'D \& Rajabi, 2018, (Katemba, 2019). This statement shows that the improvement of vocabulary in quantity and quality is needed.Understanding the vocabulary is not only in lexical items but also in lexical phrases. This is the main problem faced by the young people at English Lover Community Ende. The lack of mastery of English vocabulary causes them to feel insecure in the process of mastering English. Meanwhile, the relationship between vocabulary mastery and language use is complementary because vocabulary knowledge can allow someone to use language well and conversely the use of language causes an increase in one's knowledge of the vocabulary, Nation in (Alqahtani, 2015:2), (Heidari et al., 2012). Because of the importance of mastering vocabulary in language use, we took the initiative to carry out Community Service activities for the English-loving community by utilizing the surrounding natural environment (Ende beach tourism object) as a learning resource. This location was chosen because of its location which is quite easy to reach, and the natural beauty of the surroundings supports English language learning activities; including the number of interesting objects that can be used as a source of learning inspiration. Learning with the "nature exploration" technique was also chosen as an alternative way to foster a sense of interest and love for the English world, because a good natural environment will actually have a positive influence on the learner, Indrakusuma in (Choiri, 2017). In addition, to reduce the level of saturation of the ELC Ende participants who have tended to learn English indoors.

The general purpose of this community service activity is to use the Ende Beach tourist attraction as a source of learning English to improve the English language skills of Ende's English Lover Community (ELC) participants.Operationally, the English language skills referred to are 1) increasing the vocabulary mastery of Ende's English Lover Community (ELC) participants, the improvements referred to include increasing vocabulary both in quantity and quality, 2) arranging the learned English vocabulary into English sentences, 3) arrange English sentences that have been arranged into English paragraphs, and 4) re-express the sentences that have been arranged into the good and correct English pronunciation. The urgency of this activity for ELC Ende is to improve their basic English skills by utilizing the surrounding environment as a source of learning inspiration. For the service team, it is an effort to develop themselves to carry out community service and research related to the same issues both in the same community and in other English-loving communities in an effort to improve the English language qualifications of the current generation.

\section{METHOD}

The method implemented to answer the objectives of this community service activity is in the form of mentoring. The mentoring activities were carried out in several meetings by involving a team of English-loving lecturers who have competence as English mentors and 15 partner participants who are members of the English Lovers Community (ELC) Ende. The following are the stages of organizing that are carried out:

a. Preparation Stages

The preparatory stage carried out includes:

1) Interviewing ELC participants,

2) Observing and determining the location and target,

3) Preparing materials / materials for mentoring, 
4) Preparation of test questions to determine the participants'initial abilities and also test questions to measure the participants' final abilities after the provision of assistance activities through the use of the Ende beach tourism object as a source of learning English.

b. Mentoring Implementation Stages

At the mentoring implementation stage, several techniques are used, including:

1) Interactive lecture technique; interactive lectures are intended so that participants gain knowledge related to English language skills.

2) Question and Answer; this technique is very important for participants because it provides a question space for the participants who have difficulty in understanding the material.

3) Contextual learning; provide opportunities for participants to observe and find the learning objects around the Ende beach, connect them with new vocabulary related to English and compose them in English sentences.

4) Discussion method; discussing the findings (vocabulary) through the use of Ende beach tourism objects with group colleagues before doing repeated exercises / drilling.

5) Drill / drilling technique; This technique emphasizes the implementation of training activities (Sanatun A, Nurul, Sulisworo, 2017). In this community service activity, drill / training specifically aimed to improve English Vocabulary pronunciation skills, writing, reading and listening skills.

6) Technique demonstration; re-demonstrating the assistance material in the form of pronouncing English vocabularies, composing simple English sentences, arranging these simple sentences into a simple story (simple paragraph) and telling it verbally with the right utterances or pronunciations.

c. Final Stages

1) Post-Test

To measure the extent to which the English Lover Community (ELC) participants mastered the English language through the use of the Ende Beach tourist object as a source of learning English, a post-test was carried out.

2) Making activity reports by publication the results of activities.

\section{MAIN RESULTS AND DISCUSSION}

Community service activities are preceded by interviewing ELC participants as partners in order to find out the real problems they are facing. After finding the real problems faced, the PKM team formulated appropriate solutions to solve these problems. These solutions are expected to answer the formulated objectives of community service activities. The mentoring activity for the ELC Ende participants was followed by a pretest of the participants' English skills. This is done to measure the extent of the participants' English proficiency prior to mentoring. The aspects assessed in this pre-test are vocabulary mastery which includes writing and pronouncing English words, combining vocabularies into English sentences, recompiling English sentences into simple paragraphs and re-expressing English sentences with proper pronunciation. These aspects as a whole are designed to cover the four English language skills in which these four skills form a complete unit that is able to foster an increase in the abilities of the participants. The results of the ELC participant's English pre-test are presented in the following frequency table: 
Table 1. The Data of English Ability in Pre-Test

\begin{tabular}{|c|c|c|c|}
\hline No & Score & Frequency & $\begin{array}{c}\text { Percentage } \\
(\%)\end{array}$ \\
\hline 1 & $40-44$ & 1 & 6.66 \\
\hline 2 & $45-49$ & 0 & 0 \\
\hline 3 & $50-54$ & 4 & 26.66 \\
\hline 4 & $55-59$ & 0 & 0 \\
\hline 5 & $60-64$ & 4 & 26.66 \\
\hline 6 & $65-69$ & 1 & 6.66 \\
\hline 7 & $70-74$ & 3 & 20.00 \\
\hline 8 & $75-79$ & 2 & 13.33 \\
\hline 9 & $80-84$ & 0 & 0 \\
\hline Total & & 15 & $100 \%$ \\
\hline
\end{tabular}

The table above shows the average score obtained is $60.33 \%$. With the lowest score in the range of scores of 40-44 as many as 1 participant and the highest score in the range of scores of 75-79 as many as 2 people. This shows that English language skills are still low and still far from the expected reality. So the next step to take is a mentoring activity.The mentoring activity begins with an interactive lecture. Regarding the interactive lecture activities carried out, it can be seen in the image below:

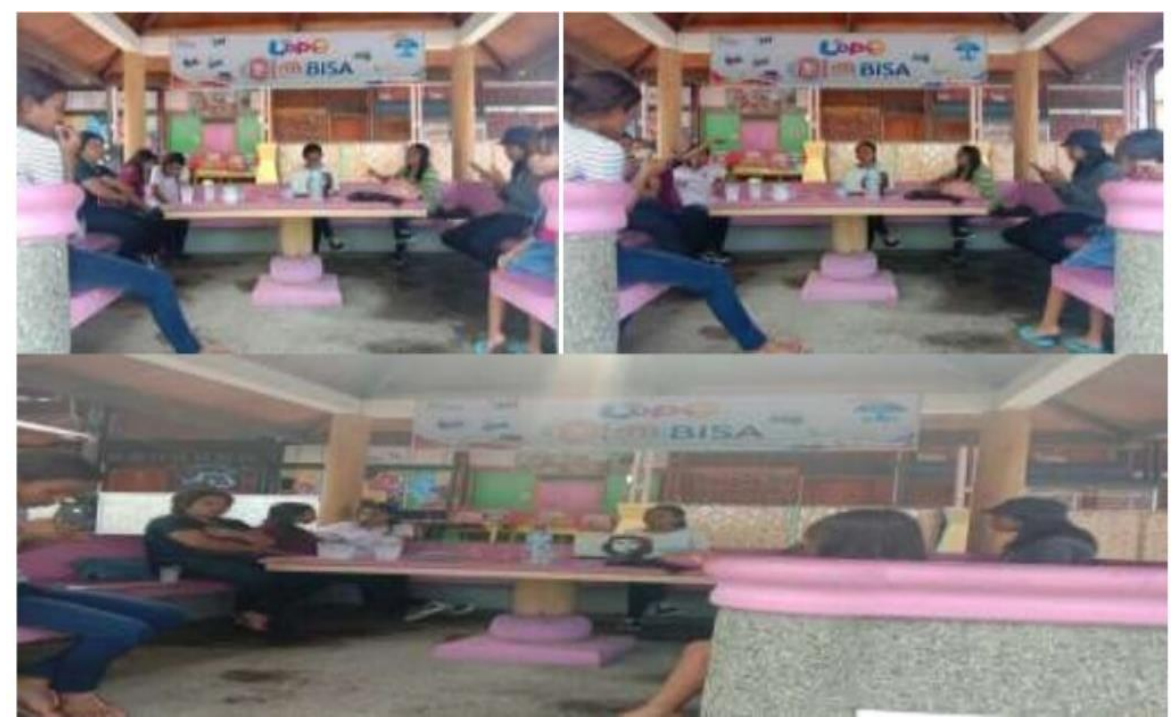

Figure1. Interactive Lecture

The interactive lecture was held at one of the Lopo in Ende Beach. In particular, the lecture material given was "The Important of English in Today's World". The contents of this lecture are in the form of backgrounds on why someone should master English, the role and function of English in the modern world, and specific tips for mastering the four skills in English (speaking, reading, listening and writing). This interactive lecture was followed by a dialogue / question and answer between the participants and the instructor. One of the most challenging questions is "How to increase our confidence in speaking English?'"These questions were then discussed by all of the participants; all participants were given the freedom to express their own opinions using bilinguals 
(English and Indonesian). The technique in using bilingual spontaneity in this discussion is to train participants' self-courage in speaking, and also to eliminate the participants' doubts in speaking English properly and correctly. The activity was continued by observing the objects or contextual objects around the Ende Beach in groups. This activity was carried out with one guide question from the PKM companion "what do you see in around of you?" All these objects that can be sensed are recorded and then translated into English.
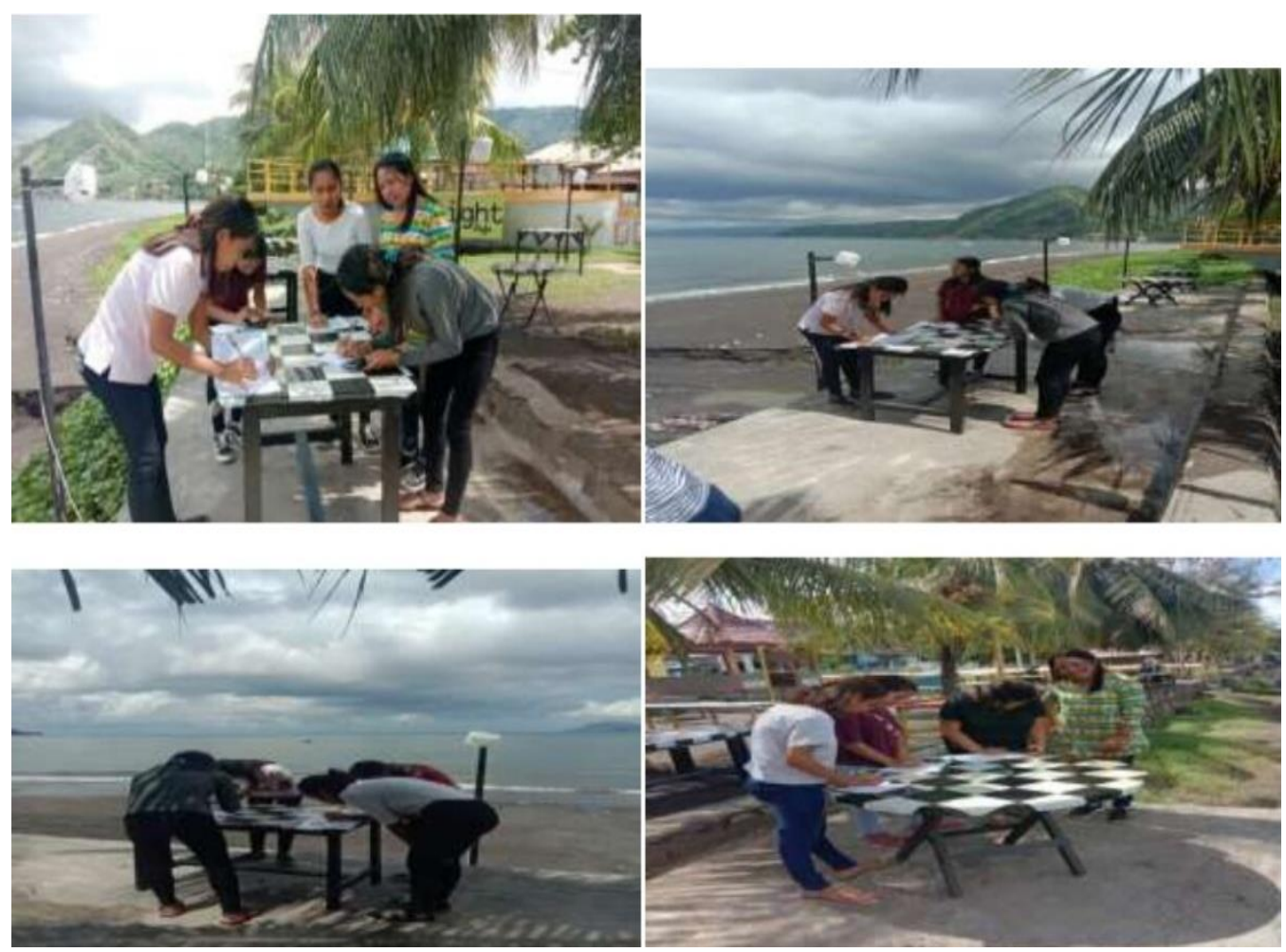

Figure 2. Observing \& Recording Objects in the Environment Around Ende Beach

Observing objects that can be sensed around Ende beach is one of the initial techniques for seeking the inspiration of knowledge because it has been said that a pleasant environment will have positive implications for learners. The results of natural observations in this PKM activity recorded about 80 new English vocabularies that could be found. For participants with lay backgrounds such as young people who are members of the ELC, this is an extraordinary achievement. Because the nature around the Ende beach has led them to be able to interpret the knowledge they had before. This contextual learning provides new experiences for ELC Ende participants, so that the knowledge they gain is more meaningful. The activity was continued by accompanying the participants to learn how to pronounce English Vocabularies that they had found in the previous observation activity correctly, assembling the vocabulary into the simple English sentences then proceed with stringing these simple sentences into a simple story and tell it verbally with a proper sayings or pronunciations. In this stage, participants are directed to use drill (practice) techniques repeatedly so that participants are able to produce pronunciation correctly. After drilling activities, the assistance was continued with a demonstration. 


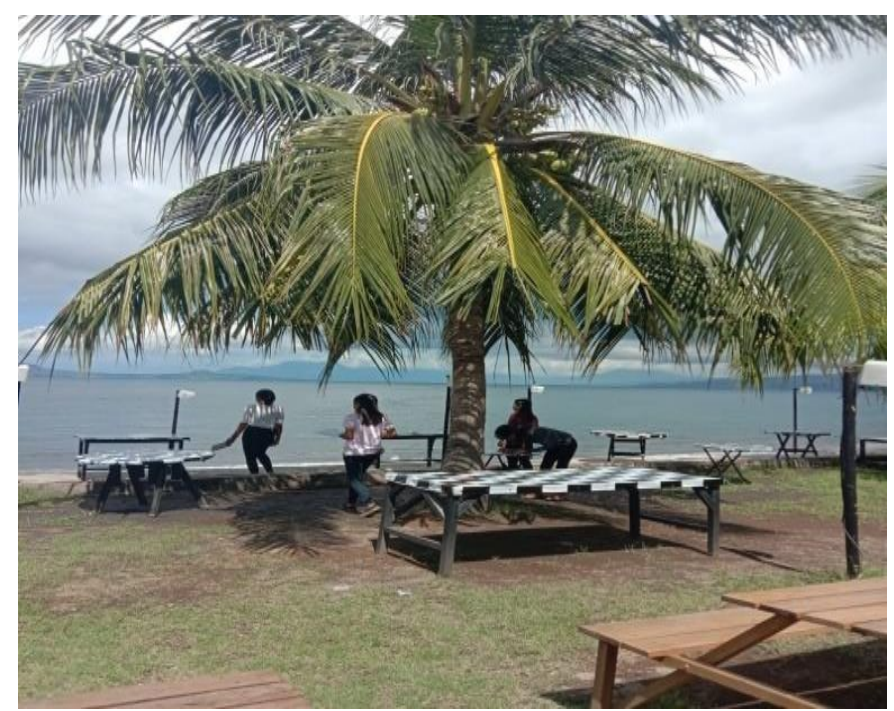

Figure 3: Some ELC Participants doing Drilling \& Demonstration

The demonstration is intended to reinforce the exercises that have been carried out in the drilling section. An example of the results of the activity generated in the demonstration is the development of the words, such as "sea", "beach", "coconut". These words are assembled into simple sentences. Then these simple sentences are woven back together to become a simple story. For example: "I see the sea water, its color is blue. The blue sea makes me happy; I love the Ende Beach so much". "There are many birds in the sky. Fly high around the Ende Beach. My heart is really happy. See the beauty of God's creation". "I looked at the tops of the coconut trees. Hear the birds singing melodiously, The sea breeze provides coolness on a pretty hot day". These sentences are representations of the example sentences demonstrated by the participants. There are many more English sentences that they create themselves. This proves that vocabulary knowledge can allow someone to use language well and conversely the use of language causes an increase in one's knowledge of the vocabulary, Nation in (Alqahtani, 2015), (Heidari et al., 2012), (Katemba, 2019). It means that the nature of Ende Beach really provides positive inspiration for the participants in their efforts to improve their English language skills. After going through various stages of mentoring, the activity ended with a post-test. The post-test scores of ELC participants are presented in the following frequency table:

Table 2. The Data of English Ability in Post-Test

\begin{tabular}{cccc}
\hline No & Score & Frequency & Percentage $(\%)$ \\
\hline 1 & $60-64$ & 0 & 0 \\
2 & $65-69$ & 0 & 0 \\
3 & $70-74$ & 3 & 20.00 \\
4 & $75-79$ & 2 & 13.33 \\
5 & $80-84$ & 5 & 33.33 \\
6 & $85-90$ & 4 & 26.66 \\
7 & $95-100$ & 1 & 6.66 \\
\hline Total & & $\mathbf{1 5}$ & $\mathbf{1 0 0 \%}$ \\
\hline
\end{tabular}

Average Score $=\underline{1220}=81.33 \%$ 
The post-test is intended to measure the extent to which the English language skills of the ELC Ende participants have improved after mentoring was held by the mentoring team. The aspects that are assessed at this stage are those related to the four English language skills. It begins with a vocabulary and pronunciation (listen and repeat) mastery test, then continues with writing (assembling vocabulary in English sentences, and weaving English sentences into short paragraphs), then reading and speaking. The score distribution table at the post-test stage shows an increase in the scores of ELC participants. The total average value obtained was $81.33 \%$ with the lowest range of values from 70-74 as many as 3 people and the highest value reaching the value range of 95-100 as many as 1 person. This shows a significant increase in the students' English proficiency between before and after mentoring. Thus, it can fulfill Indrakusuma's statement in, (Choiri, 2017) that a good natural environment will actually have a positive influence on the learner.

After the mentoring activity ends, the service team makes a report on the results of the activity. Matters that support this reporting activity include the results of initial interviews with English Lover Community Ende participants, activity observations, pretest and post-test results to measure English proficiency and other supporting data in the form of verbal statements during the mentoring activity. The report on the results of this activity is then made in a community service article for publication.

\section{CONCLUSION}

In general, the general objective of implementing community service activities through the use of Ende Beach tourism objects as a source of learning English have a positive impact on the English language skills of Ende's English Lover Community (ELC) participants. The English language proficiency in question is an increase in vocabulary mastery of Ende's English Lover Community (ELC) participants, both in quantity and quality. Besides that, it also gives positive implications for the ability to assemble the learned vocabulary into English sentences and re-express the sentences that have been strung into good and correct pronunciation of English. The increase in the ability of participants is also seen from the ability to assemble English sentences into English paragraphs and read the paragraphs using the English pronunciation correctly. The urgency of this activity is for ELC Ende; making them the generation with the basic English skills; generation who are not English literate by utilizing the surrounding environment as a source of learning inspiration. For the service team, this activity becomes the basic foundation for carrying out similar service to other English-loving communities and as an effort to develop themselves in conducting research related to the same subject both in the same community and in other communities. Suggestions that can be conveyed to service providers and other servants who have an interest in doing similar PKM are to make the findings in this PKM as a basic basis for follow-up activity as an effort to improve the participants' English proficiency in more depth.

\section{REFERENCES}

Alqahtani, M. (2015). The Importance of Vocabulary in Language Learning and How To Be Taught. International Journal of Teaching and Education, III(3), 21-34. https://doi.org/10.20472/TE.2015.3.3.002

Choiri, M. M. (2017). Upaya Pemanfaatan Lingkungan Sekitar Sebagai Sumber Belajar Anak. Refleksi Edukatika: Jurnal Ilmiah Kependidikan, 8(1). https://doi.org/10.24176/re.v8i1.1793

Geoffrey, Broughton, Brumfit. C., Flavell. R., Hill. Peter, P. A. (2003). Teaching English 
as A Foreign Language (J. Eggleston (ed.); Second, Issue 1). Routledge. https://doi.org/10.16309/j.cnki.issn.1007-1776.2003.03.004

Heidari, F. L., Karimi, F., \& Imani, A. (2012). Vocabulary learning strategy instruction: It's impact on English for specific purpose vocabulary achievement and reading comprehension. Middle East Journal of Scientific Research, 12(11), 1488-1496. https://doi.org/10.5829/idosi.mejsr.2012.12.11.379

Katemba, C. V. (2019). Students' vocabulary enhancement at grade 10: A comparative study using CALL \& MALL in Indonesia. CALL-EJ, 20(1).

Kurniawan, I. (2016). Measuring EFL Students 'Students 'Vocabulary Size: Why and How (Vol. 9, Issue 1).

Nishanthi, R. (2018). The Importance of Learning English in Today World. International Journal of Trend in Scientific Research and Development, Volume-3(Issue-1), 871874. https://doi.org/10.31142/ijtsrd19061

Reddy, M. S. (2016). Importance of English Language in Today's World. International Journal of Academic Research, 3(4), 179-184. www.ijar.org.in

Sa'D, S. H. T., \& Rajabi, F. (2018). Teaching and learning vocabulary: What English language learners perceive to be effective and ineffective strategies. Center for Educational Policy Studies Journal, 8(1). https://doi.org/10.26529/cepsj.492

Sanatun A, Nurul, Sulisworo, D. (2017). Implementasi Metode Drill and Practise Secara Kelompok Untuk Peningkatan Prestasi Belajar. Unnes Phisics Education Journal, August.

https://www.researchgate.net/publication/318982302_IMPLEMENTASI_METOD E_DRILL_AND_PRACTICE_SECARA_KELOMPOK_UNTUK_PENINGKAT AN_PRESTASI_BELAJAR/link/598940fe45851560584fea0c/download 